\title{
Aleppo II: Not Bringing the State Back in
}

\author{
Jan-Erik Lane* \\ Fellow with Public Policy Institute, Belgrade, The Republic of Serbia \\ Email: janeklane@gmail.com
}

How to cite this paper: Lane, J.-E. (2017). Aleppo II: Not Bringing the State Back in. Open Journal of Political Science, 7, 55-64. http://dx.doi.org/10.4236/ojps.2017.71005

Received: October 22, 2016

Accepted: December 2, 2016

Published: December 5, 2016

Copyright $\odot 2017$ by author and Scientific Research Publishing Inc. This work is licensed under the Creative Commons Attribution International License (CC BY 4.0).

http://creativecommons.org/licenses/by/4.0/

\begin{abstract}
The political violence seems only to get worse and worse in Aleppo, where Russian bombers target hospitals and employ deep striking missiles against the apartments of ordinary citizens. State reasons or merely shortsighted cruelty? Those who theorize zero sum games with entities like state interests and geopolitical perspective should understand that it is merely a manner of speaking. The principle of methodological individualism entails that only human beings can be actors as well as that they orientate in terms of what Max Weber called "Sinn" or more complex "sinnzusammenhaenge". This is intentional analysis that focuses upon the mindset of the participants in violent games. It is definitely not in the interests of neither the Syrian people nor the Russian people what Assad-Putin is performing in Aleppo.
\end{abstract}

\section{Keywords}

Reasons of State, Methodological Individualism, "Bringing the State Back in", Subjective and Objective Benefits, Costs and Probabilities, Means-End Relationships, Alawites

\section{Introduction}

The battle for Aleppo ranges on, displaying all the monstrous horrors of modern warfare. This city in the centre of war torn Middle East will go down in memory as another Babi Yar. One must attempt to theorize the rationale of what is going on a daily basis with the slaughtering of innocents and the massive destruction of capital assets. Where are people to stay when their houses and apartments are systematically demolished by inter alia Russian bombings from its Sokhoi aircrafts? The Syrian nation is being completely destroyed with thousands deaths and millions in refugee camps in many countries, not to speak of those drowned in the Mediterranean Sea.

Why is all this occurring before our eyes? Turning to the international relations literature, one finds no attractive explanation. International relations theory is replete with unscientific notions about the state as actor, driven by the flawed notion of state reasons 
or interests. This kind of concept set violates the principle of methodological individualism, which entails that only persons can be actors and that the motivation of people is made up of their intensions. The mind entities of values, beliefs, preferences and subjective probability estimates are central in theorizing the Syrian wars and the Aleppo atrocities-what Max Weber called "sinnzusammenhaenge".

\section{Rejection of the State Perspective on Warfare}

Under the banner "bringing the state back in", T. Skocpol (1985) launched a renewal interest in state theory, but it cannot work in scientific theorizing. The "state" is merely a legal fiction, employed for institutional and organizational purposes, like taxation, budgeting and the requirement of public responsibility. Actions meaning intended behavior can only be attributed to human beings, either in solitary or collective activity. It is the set of actions that make the social sciences differ from the natural sciences. And the key to understanding action lies with mind concepts like preferences, beliefs and subjective probability.

An elaborate position stating methodological individualism is to be found in Weber's methodological writings (Weber, 1922, 1984), badly underestimated in the philosophy of the social sciences in particular and the philosophy of science in general. He stated:

(WQ) Every thoughtful reflection on the ultimate elements of meaningful human action is immediately tied to the categories of means and purposes. (Weber, 1949: p. 52).

Starting from Weber's basic methodological principle, we must say that when the US declares war on Japan in 1941, the actors are made up the President and the Congress. As they declare war on Japan in the name of the state, the decision has to be understood in terms of their min sets: beliefs, preferences and subjective probabilities. The same applies to the Russian tactics and strategy in the Syrian war, depending not upon the Russian state and its purported reasons, but upon the mindset of the circle around President Putin.

Weber spoke of elaborate mind sets-sinnzusammenhaenge-with key actors, collapsing them in the concepts of ends and means. He also included action that is fanatically oriented towards merely an objective without causal beliefs about the instruments that promote goals: end action against means end action. To him, only means end activity could be reasonable, as it involved calculation, i.e. causal beliefs.

The Weber emphasis upon the "inner" dimension of action is not accepted fully in American behaviorism or behaviouralism that speaks of human activity as sets of behavior, and not action as intended behavior. For the social sciences, it is essential to approach human activity and social systems with mind categories, rejecting physicalism, as with logical positivists, or mind-body reductionist paradigms, as in some philosophy of science.

In his translation of texts by Weber, Parsons (Weber, 1947) employed the word "orientation" to denote this mind focused nature of human action. Behaviour is orientated in terms of ends and means, i.e. preferences, beliefs and subjective probability estimates. Parsons, as it well-known, underlined the role of value orientations in the 
"sinn" of an action. To speak of a rationale is to target the motivation of an actor or group of actors, the "sinnzusammenhaenge". Modern rationality, argued Weber (1978), is based upon means-end rationality, but today we observe lots of end rationality with people in terrorism or extreme religious activity with a political purpose.

\section{Rejection of Objective State Interests}

It is now argued that Putin is advancing the interests of Russia in the Middle East by involving Russian military forces in the Syrian civil war. It is even commented that he is skillfully pursuing Russian state reason while the US appears weak and indecisive, reluctant to regard more military involvement in this region as state reason. However, this is merely journalistic talk.

The classic theory of state reason, according to historian F. Meinecke $(1907,1957)$ claimed that states have objective interests that may go beyond the preferences or values of its inhabitants. Such reasons may be discovered not through preference revelation mechanisms like voting or the referendum but through neutral and impartial enquiry in to situation of the country: borders, economy and needs. The discipline of geopolitics was constructed on the basis of this idea of objective state interests, just waiting to be discovered before acted upon as a duty of rulers.

To make the point in a short manner: Russia as a nation has no interests at stake in Syria, as the country's citizens long for economic affluence and peace. Putin believes that Russia does have reasons to be in Syria, but it is only a belief a wrong one too, as key actors often make mistakes. The values at stake in Syria concern various interests of religious groups, especially the minority Alawites with a somewhat special Shia creed, and they fall outside of the main values of Orthodox Russia with a Communist legacy.

This is the third time Russia gets itself involved in a Muslim conflict. The first was the Israel wars that were very costly in terms of resources and war materials for Soviet Union. Afghanistan was the second, which ended in total Russian defeat with terrible human losses. Now Putin wastes Russian resources on a Muslim civil war, destroying the reputation of Russia as a civilized nation.

One may remind of the disastrous foreign policy of Nazi Germany when one wishes to demolish the notion of geopolitics harbouring state reasons. Instead one must speak of the reasons of Hitler, his own speculation in military grandeur and his attribution to Germany of social values the promotion of which brought the country to extinction in 1945. Objective state interests?

Now, why this unending vicious civil war in Syria, an old country from the dawn of human civilization?

\section{Types of Conflicts}

The Aleppo battle is an example of a political conflict, because it is orientated in the motivations of the players towards the exercise of power in government and the making of public policies. Political conflicts need not be violent, as there exist peaceful conflict resolution mechanisms. There will a long debate over why the players in the Syrian civil war walked away from negotiating a peaceful solution, because there are no winners here, only losers, dead or alive with enormous capital destruction. 
Other kinds of conflicts comprise personal ones, mental inner conflicts within one person, religious disputes, academic conflicts, game struggles, etc. Here, we model political conflicts of a violent nature with Syria as our prime example.

\section{The Logic of the Attack}

When a government or a rebel group takes up arms starting warfare, they engage in instrumentally rational action, orientated in terms of means and ends. What the chief objective may be varies from one conflict to another, but the orientation towards the use of force as a means entails that the actors involved have beliefs, values and subjective probabilities. The first attach is of course only a step in a sequence where attack and defense, counterattack and defense follow upon each other. A war is a sequence of plays with iterated choices until the final round of play. Sequential play may comprise a series of wins and losses, but the final round is of course decisive for the outcome. In each stage in the sequential play, the players have a mindset involving their intensions or motivations.

Of course, the orientations of the players change all the running of the sequence, as they update their beliefs changing their subjective probabilities and revising their values. It is this dynamic interaction between the players, their orientation and the outcomes experienced that must be modeled in a warfare model.

The government or rebel group who orders an attack on some other persons or groups or governments must satisfy individual rationality, which is the same condition in all kinds of human behavior, namely:

1) $\mathrm{Bi}>\mathrm{Ci}$, for any actor $\mathrm{i}$,

or the benefits must be larger than the costs for the actor i. During a war, situations may arise where this inequality does not hold, but at the start of war it seems a reasonable assumption. Now, the equation is amorphous and elliptical, because what matters are the expectations of the actor(s) about benefits and costs. Thus, we must add beliefs and subjective probabilities to the Equation (1).

A simple way to emphasize the subjective nature of benefits and costs in the equation (1) is to employ a sign for expectations *. Thus, a requirement of rationality in warfare is as follows:

2) ${ }^{\star}$ Benefitsi $>{ }^{*}$ costsi.

A key element in these expectations of gains and losses is made up of subjective probability estimates of how likely various future scenarios are. Basically, these are beliefs about what the enemy will do, given what the initiator of an attach does, as well as the successfulness of the attack.

These subjective probabilities must be sharply distinguished from the objective probabilities that hold for a neutral and impartial observer of the conflict, the "true" situation as it were. Typical of warfare is that

3) *benefitsi and ${ }^{*}$ costsi differ from $\lambda$ benefits and $\lambda$ costs, where $\lambda=$ true probabilities or objective likelihood.

\section{The Inherently Subjective Nature of Violent Conflicts}

By distinguishing sharply between expectations about benefits and costs on the one 
hand, and the likelihood of advantages and disadvantages on the other hand, one arrives at the crucial role in violent conflicts of the mistake(s). Actors in political conflicts tend to badly informed, display opportunism with guile about gains and losses, underestimate costs and exaggerate benefits. When the role errors in calculation and mistakes in evaluations are taken into account, one arrives at the unavoidable conclusion that politically violent conflicts are most of time foolish.

One need not refer to spectacular mistakes like Alcibiades' eccentric campaign on Syracuse, Napoleon's great gamble in marching towards Moscow and Hitler's illequipped Barbarossa Operation. It is enough to refer to the Syrian conflict that has lasted an incredible 5 years with no decisive outcome whatsoever.

All the participants in this conflict know that Aleppo will go down in human history as extremely ferocious, with terrible consequences for the Syria population, on par almost with names like Srebrenic and Nanking. The participants have completely false expectations about benefits and costs, but they keep fighting very day because their support from others is far from dwindling. Thus, one cannot hope that one side gives up due to the exhaustion of outside supporters.

The participants are:

- Assad and his Alawite group;

- Putin and Russian air force;

- The rebels from the Sunni majority, in several factions;

- The ISIS or ISIL-Sunni terrorists;

- Hezbollah and Iranian volunteers-Shia fundamentalists.

- Rest of the Syrian people in a multicultural setting. Speaking of $\lambda$ benefits and $\lambda$ costs, we have for the key active players in this warfare:

- Assad's clan-the Kalbiyya: stay in power at whatever cost to the Syrian people;

- Alawites: support Assad's clan as long as they can guarantee the safety of this religious minority;

- Putin and his "entourage" in theKremlin: support an old ally, be loyal to an old cause, display Russian military force without risk of Western involvement-all camouflaged by talk of "Russian Interests" in the Middle East;

- Sunni Rebels: to end the long dictatorship of the Assad clan, which brought so much economic advantages to the Alawites and so much oppression to dissidents whatever comes after;

- ISIS: to kill the Alawites and other Shias, Christians and non-Muslims in Syria in order to integrate the country in the new caliphate in the Middle East;

- Hezbollah and Iran: to make sure that the Assad regime does not fall to any Sunnis;

- Syrian people: peace, rule of law and prosperity.

However, the players in the conflict adduce other things as their ${ }^{*}$ benefits and ${ }^{*}$ costs, like:

- Assad: protect the integrity of the Syrian state;

- Putin: geopolitical needs of Russia or Russian state reasons;

- The Sunni Rebels: democracy;

- ISIS: "true" Islam: completeislamisation, re-introduction of the caliphate and total jihad. 
The rhetoric of Assad and Putin fits well with the classic theory of state reasons and likewise with the geopolitical approach to international relations and foreign policy, both of which violate the principle of methodological individualism.

It should be pointed out strongly that the Syrian social structure is much heterogeneous with several ethnic groups and religious sects. It is even difficult to tell what the Alawites stand for: Are they really Twelvers like the Iranian majority or some mix of "Nusayris"? Besides, there are other kinds of Shias or Shites in addition to different types of Christians like Armenians or "old" Christians. For Assad, the real interests are power and economic advantages, for Putin his personal prestige and for the Sunni rebels and ISIS to finish with the Shia regime.

To display the hollowness of the terms "state interests", "state reason" and "geopolitical strategy", I will discuss two recent books by George Friedman that have aroused much attention. Of course, Assad does not take Syrian interests into account and Russia needs no colonial position in the Muslim civilization, neither now nor in the 1970s or 1980s.

\section{The Unscientificness of Geopolitical Inquiry}

Friedman conducts geopolitical enquiry, eliciting state interests from geographical factors, always with a specific view, namely that of the US. A close reading gives the following remarks:

1) Contradictory: In his first book (2009), Friedman argues that Russia will go down under during the 21rst century, invaded by China, the EU and Turkey, which is nonsense in itself; but in his second book (2012), Friedman states that a great danger to the US position in the world is a likely alliance between Germany and Russia to dominate Euro Asia. Both propositions cannot be true. And why would Kant attempt to marry Dostoevsky?

2) Speculative: Friedman argues that Brazil may challenge US hegemony in the Atlantic by lining up with Angola, economically and militarily. Again nonsense, as both countries are fundamentally instable ones.

3) Opportunistic: Friedman states that the US should not hesitate to play double games in order to fool both Japan and China, if it suits its interests. Such games would be immediately seen through for what they are: dishonesty.

4) Historicism: Both books promise and analysis of future scenarios and their probabilities, but they are full of historical narratives, some of which are truly superficial. For instance, the German disaster in the $20^{\text {th }}$ century is analysed with the old model of two states on the flanks, but Friedman does not mention Bismarck's land grab in 1871 of vital French territories (Alsace-Lorraine), not does he describe the fatal choice of Hitler to continue aggression after the Munich triumph. Had Hitler restored the Weimar Republic in 1938 and respected its Rechtsstaat (also for Jews), then his reputation among Germans would have been much different. War results from choices, not geography.

5) Platitudes: Africa is described as of no interest to the US, as if human rights and rule of law in Sub-Saharan Africa were of no concern to America.

6) Disregard of relevant values: Friedman states that “...all nations..." are "brutally egoistic" (Friedman, 2012: p. 222), reminding us of Morgenthau's perspective on international relations (see below). But game theory has proved that egoism in interactions 
lead to "rational foolishness" or coordination failures. Thus, even if Friedman's hypothesis about the motivation of "nations" would be true, game theory entails the need for norms, like Public International Law. Friedman has nothing to say about the PIL or regional organisations that restrain state egoism-compare (Keohane, 2005).

\section{Difference between ${ }^{*}$ Benefits or ${ }^{*}$ Costs and $\lambda$ Benefits or $\lambda$ Costs}

Making a sharp conceptual separation between starred ${ }^{*}$ demands or ${ }^{*}$ costs on the one hand, and $\lambda$ demands or $\lambda$ costs on the other hand, allows us to emphasize the immense role that human mistakes play in warfare or violent political conflicts. Whichever famous war or battle you examine, one is bound to observe errors and mistakes concerning:

- Benefits (overexaggerated),

- Costs (underestimated),

- Subjective probabilities (wrong beliefs about means-end),

- Mean-end relationships, i.e. instrumental rationality.

This distinction between the starred ${ }^{\star}$ elements and the $\lambda$ elements goes a long way in helping to understand the tragedy of politically violent conflict as well as warfare. Often the real benefits for the attacker are minimal while the costs become astronomical, due to faulty means-end beliefs. Theorizing these discrepancies between imagined benefits and costs on the one hand and real outcomes on the other hand, we introduce two new concepts: updating as well as the Zermelo point.

\subsection{Updating}

True information is extremely essential in zero sum games. Thus, the players engage all the time in updating to minimize the distance between ${ }^{*}$ benefits or ${ }^{*}$ costs and $\lambda$ benefits or $\lambda$ costs. What is crucial to the end is to have adequate causal knowledge, i.e. more information about the mean-end relationships involved.

One method to increase relevant knowledge is to take past lessons into account. They are very negative for Putin's engagement in Syria. The Soviet Union paid a fortune to Egypt and Syria in the 1950s, 1960s and 1970s, receiving nothing back for all its technical assistance and massive arms material transfers. Likewise, the invasion of Moslem Afghanistan resulted in lots of deaths and most heavy casualties for young Russian soldiers. For Syrian interventions holds that innocent Russian have been killed already. If Assad steps down or falls, Russia is a sucker again. The alliance with the Shiite civilization is not congenial to an Orthodox country, as it is merely Putin's figment of imagination of ${ }^{*}$ benefits and ${ }^{*}$ costs. Perhaps the losses of Napoleon were due to increased incapacity or willingness to updating efforts?

\subsection{Zermelo Point}

As a result of the intense Russian bombardments against all kinds of people linked somehow with opposition to the Assad regime, the civil war in Syria has become more amorphous than ever. It has no end in sight, as the warring factions are far from exhausted, supported as they are by foreign powers. The Syrian people pay an incredible price for Assad's unwillingness to negotiate a regime transition. 
Zermelo, mathematician at Freiburg University, delivered the first major theory early in the $20^{\text {th }}$ about zero sum games with his hypothesis about a decisive point of the game when played in sequence, like in warfare. There has been a long debate about what the Zermelo point entails, but his application to chess reveals his intent. It is not a speculation about whether chess is determined from the beginning (win or remis), as some scholars have argued wrongly.

Every skilled chess player knows that as the game unfolds one arrives at a stage in this sequence that is decisive, which entails that the outcome is strictly determined (win, remis). From this node, the rational player can FORCE the outcome-i.e. the Zermelo point or a kind of sub game Nash equilibrium for a sequence of zero sum gaming.

The Russian intervention in Syria has made this terrible game completely open, meaning that many more civilians will die.

\section{Evilness, War and Political Conflict}

Morgenthau (1978) derived the proposition of Friedman "all nations... are brutally egoistic" from human nature, war being the prolongation of people's fighting instincts. Thus, political conflict is unavoidable and the Hobbes' recommendation follows: Arm yourself if you want to live in peace. Interestingly, Morgenthau was not only under the influence of Carl Schmitt, but he also received much stimuli from Kelsen $(2006,2009)$ during his Geneva period in the 1930s (Frei, 2001). Thus, Morgenthau recognized that unlimited selfishness must be restrained by norms. We find this opposition or antimony between egoism and normativity in the entire history of political thought, from the post-Socrates to the intense debate about the validity of public international law today.

This discussion on human nature has involved wide differences of opinion among the epicureans, cynics, stoicists, scholasticism, Hobbes, Spinoza, Locke and Rousseau among the great historical personalities as well as Lorenz (1980) and modern biology today. I side with Spinoza in his remarkably original and truly underestimated Tractatus Politicus (2005), where he launched a defense for the democratic regime, starting from Hobbes' description of the state of nature (2008), without any Lockean assumption about altruism and its human rights catalogue. In the debate today, it seems to me that egoism as the starting assumption for a social contract is more fertile than the Rawls- Dworkin (Rawls, 1999; Dworkin, 1977) natural law assumption (Gautier, 1999). But naked selfishness defeats itself.

It is amazing how Putin has changed towards an aggressive set of policies, both domestically and internationally, almost as if he believes he lives in a Hobbesian jungle. Is Russian never going to experience the $\lambda$ benefits of the well-ordered society with a rule of law regime? Putin employs too much political violence that is out of touch with the needs of Russian people just like the Tsars and the Communist leaders. Why no rule of law in Russia?

\section{ASSAD and His Kalbiyya, the Alewites and Shura}

The cruelty of the Assad-Putin war in Syria in general and Aleppo in particular can only be understood as a strategy or tactics suitable for the natural state of Spinoza, where no legitimate state or set of norms restrain egoism. Assad put himself and his tribe or 
religious sect in this anarchy by refusing to engage in regime negotiations for a peaceful transfer of power. The mutual gains for all warring players except the ISIS would have been simply enormous. The Assad regime practices a policy of house destruction, meaning anywhere opponents can be spotted, their houses or apartments will be leveled to the ground. And Putin assists willingly in this capital demolition that now must be astronomical.

The conflict in Syria dates back to the coup detat by the Hafez al-Assad and its clan in 1971. It cannot count upon ruling Syria forever. In a negotiated regime transition, all stood to gain, but Pareto optimality did not suit Assad or the ISIS. The Syrian civil war is tragic foolishness.

A series of closely monitored referenda with international observers from the EU, the US and Russia could have paid the way for peaceful transition and the introduction of rule of law. This is Islamic SHURA at its best potential. With guarantees for the Alawites against massacres, all Syrian groups would have been better off with a comprehensive deal, except the ISIS.

\section{Conclusion}

The development of events in and around Aleppo takes us into the theory of the state of nature, where "brutal egoism" reigns. Assad and his clan Kalbiyya reject any settlement, despite that his main minority group, the Alawites, suffer enormously like the other groups in war torn Syria. The Russian intervention with heavy bombardment against civilians brings nations into the Hobbesian predicament. As there is no Zermelo point, this conflict just rages on and the Syrian people is crushed. Why no SHURA to reach a Pareto optimal deal, even today after so many deaths and much destruction?

The political conflict in Syria is as violent as war becomes, but it is not about state interests or reasons. The causes are to be found in the preferences and beliefs of the key participants, and their views about benefits, costs and subjective probabilities. As a matter of fact, the same holds for activities in international relations generally.

Friedman and Morgenthau would agree on "brutally egoistic nations" and that international relations are still played out in a Hobbesian jungle. Yet, normativity has been growing for a long time, offering norms that restrain selfishness. Had French foreign minister de Villepan been respected in the UN Security Council 2003, the Middle East would be a very different place today. Public international law is like a spontaneous order that has emerged slowly. It should always be respected, as it restrains opportunism and misconceived egoism. At the end of another bloody day, Assad-Putin must negotiate a peaceful settlement including a regime shift.

The extreme violence in the Syrian civil wars cannot simply be explained by the sharp cleavages in the history of the country, dominated by foreign intrusion, colonialism and the struggle among sects (McHugo, 2015). In addition to a history of domination and foreign intervention, the Syrian civil wars strongly corroborates the hypothesis that wars are basically meaningless and often express human aggression, if not evilness.

\section{References}

Dworkin, R. (1977). Taking Rights Seriously. Cambridge, MA: Harvard U.P. 
Frei, C. (2001). Hans J. Morgenthau: An Intellectual Biography. Baton Rouge: Louisiana State University Press.

Friedman, G. (2009). The Next Hundred Years. New York: Doubleday.

Friedman, G. (2012). The Next Decade. New York: Doubleday.

Gautier, D. (1999). Morals by Agreement. Oxford: OUP.

Hobbes, T. (2008). Leviathan. Oxford: Oxford U.P.

Kelsen, H. (2006). General Theory of Law and State. Piscataway, NJ: Transaction.

Kelsen, H. (2009). Pure Theory of Law. London: Lawbook Exchange.

Keohane, R. O. (2005). After Hegemony (Revised ed.). Princeton, NJ: Princeton U.P.

Lorenz, K. (1980, 2002). On Aggression. London: Routledge.

McHugo, J. (2015). Syria: A Recent History. Saqi Books

Meinecke, F. (1924, 1957). Machiavellism: The Doctrine of Raison D'Etat and Its Place in Modern History. London: Routledge.

Morgenthau, H. J. (1978). Politics among Nations: The Struggle for Power and Peace (5th ed.). New York: Alfred A. Knopf.

Rawls, J. (1999). A Theory of Justice (Revised ed.). Cambridge, MA: Harvard U.P.

Skocpol, T. (1985). Bringing the State Back in: Strategies of Analysis in Current Research. In P. Evans, D. Rueschemeyer, \& T. Skocpol (Eds.), Bringing the State Back In (pp. 3-43). Cambridge: Cambridge U.P.

Spinoza, B. (2005). Tractatus Politicus (Traitepolitique). Paris: Presses Universitaires de France.

Weber, M. (1922, 1984). Gesammelte Aufsaetzezur Wissenschaftslehre. Tuebingen: Mohr.

Weber, M. (1947). Theory of Social and Economic Organization (Edited with Introduction by T. Parsons). New York: Free Press.

Weber, M. (1949). The Methodology of the Social Sciences (Translation and Foreword by Finch and E. Shils). New York: Free Press.

Weber, M. (1978). Economy and Society I-II. Berkeley, CA: University of California Press.

Submit or recommend next manuscript to SCIRP and we will provide best service for you:

Accepting pre-submission inquiries through Email, Facebook, LinkedIn, Twitter, etc. A wide selection of journals (inclusive of 9 subjects, more than 200 journals)

Providing 24-hour high-quality service

User-friendly online submission system

Fair and swift peer-review system

Efficient typesetting and proofreading procedure

Display of the result of downloads and visits, as well as the number of cited articles

Maximum dissemination of your research work

Submit your manuscript at: http://papersubmission.scirp.org/

Or contact ojps@scirp.org 